\title{
Agroforestry: A Triple Win for Mixed Farming Systems in Central Rift Valley, Ethiopia
}

\author{
Ogola Robert John Ouko ${ }^{1} \quad$ Ouko Kevin Okoth ${ }^{2 *} \quad$ Niels Bouwman $^{1} \quad$ Luuk Scholten $^{1}$ \\ Thomas Kwambai $^{1} \quad$ Tika Schellevis $^{1}$ \\ 1.Wageningen University of Research, Netherlands \\ 2. Jaramogi Oginga Odinga University of Science and Technology, Kenya
}

\begin{abstract}
The Ethiopian Central Rift Valley floor faces various challenges related to reducing food insecurity, degraded ecosystems and climate change. Farming in the lower valley region is largely done under rainfed conditions, and the area's overreliance on agriculture and its very low levels of irrigation make it singularly vulnerable to the vagaries of its highly variable and changing climate. This study sought to answer the question of the effect of agroforestry as a Climate Smarts Agriculture (CSA) strategy option to improve food productivity in a mixed farming system at farm-level in Central Rift Valley, Ethiopia. To extrapolate current agricultural practices into the future, WOFOST (World Food Studies simulation model) was used to simulate the yields under the effect of climate change. For the business as usual it was assumed that the strategies currently used by farmers remained the same in the future that is application of synthetic fertiliser and unavailability of irrigation systems. However, a few parameters were changed due to climate change such as amount of $\mathrm{CO}_{2}$ in the atmosphere. The parameters that were changed included temperature, PAR, soil moisture and nitrogen deposition. WOFOST results were based on historical weather data $(1979$ - 2015) and future data (2020-2050).The results of this study showed a positive effect of agroforestry in combination with enhanced manure management. This study recommends using agroforestry with enhanced manure management as a climate smart strategy that will improve all CSA pillars. The multiple benefits associated with agroforestry, when managed well, are a viable option for smallholder farmers of the Central Rift Valley of Ethiopia.
\end{abstract}

Keywords: Crop Simulation Model, WOFOST modelling, Agroforestry

DOI: $10.7176 / \mathrm{JBAH} / 10-4-01$

Publication date: February $29^{\text {th }} 2020$

\section{Introduction}

\subsection{Background of the study}

In the Central Rift Valley (CRV) of Ethiopia, agricultural production is the main source of food and income to most rural communities, adaptation of the agricultural sector to the negative effects of climate change will be very vital to protect the livelihood of the poor and to ensure food security for their families. Hence, adaptation can greatly help the rural communities to cope with the unfavourable impacts(Adger et al., 2005). In the CRV there are two different farming systems present: the highlands and the lowlands (Silva et al., 2019). The scope of this study focussed on the farming systems in the lowlands, since the impact of climate change is likely be more severe in this area than at higher altitude. Here, the main agricultural types are smallholder mixed farms with few hectares of land available. The land consists of areas for rainfed crops and areas for livestock. The amount of livestock is generally low, and farmers have usually only one or two pairs of oxen(Silva et al., 2019). In this case study, it is assumed that a farmer has 2 hectares of land available for cropping maize and 4 cows. There will be a focus on enhancing the situation for farmers in the near future, therefore the results and recommendation will be for the timeframe of 2020 until 2050. The average result of five RCP8.5 models was used to simulate weather conditions including the effect of climate change. The following models have been used in this case study; gfdlesm2m, hadgem2-es, ipsl-cm5a-lr, miroc-esm-chem and noresm1-m.

The Ethiopian CRV floor faces various challenges related to reducing food insecurity, degraded ecosystems and climate change. Farming in the lower valley region is largely done under rainfed conditions, and the area's reliance on agriculture and its very low levels of irrigation make it singularly vulnerable to the vagaries of its highly variable and changing climate. In the last century, global average temperature has increased by $0.85^{\circ} \mathrm{C}$ and is projected to increase with $1.1-5.8^{\circ} \mathrm{C}$ by the end of this century and the rainfall patterns will change with an increased frequency of extreme event (Meehl et al., 2007; T. \& J., 2013). The impacts of increased temperature from global warming and changes in rainfall patterns resulting from climate change are expected to reduce agricultural production and put further pressure on marginal land(Lobell \& Field, 2007; van de Steeg et al., 2009).These environmental changes will greatly affect the production of food crops especially maize in this valley.

\subsection{Analysis exposure and impact future weather data}

To get an understanding of the severity of climate change in the CRV, observed and future weather data were 
used to analyse weather conditions. The results indicated an increase in the amount of days with extreme weather events for both observed and predicted data, meaning that high temperatures and extreme precipitation will become more abundant, potentially threatening crop production. On the other hands, the amount of days without precipitation will decline, enhancing the water availability for crops. The average monthly precipitation will remain almost equal, with only a minor shift of rainfall towards the second half of the years is observed (figure 1). The average monthly temperature will increase with approximately $2{ }^{\circ} \mathrm{C}$, potentially exceeding the optimum temperature for maize especially during the flowering period (Lobell et al., 2011) (figure 2).

Average precipitation

(1979-2016) vs (2020-2050)

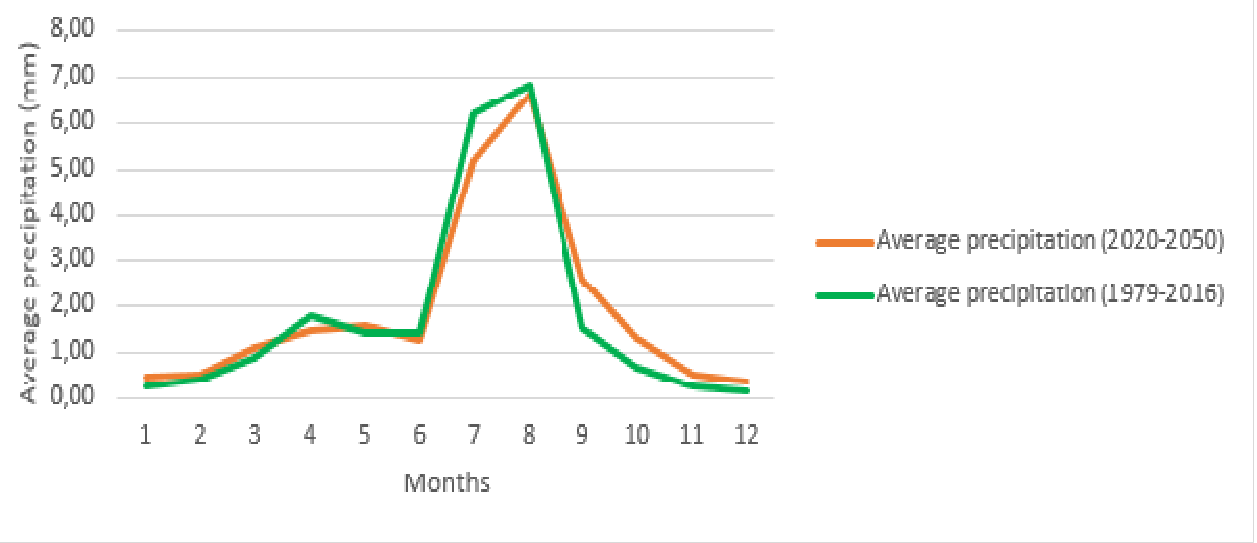

Figure 1: Average monthly precipitation of historical and predicted rainfall. Based on weather data observed and from the climate models.

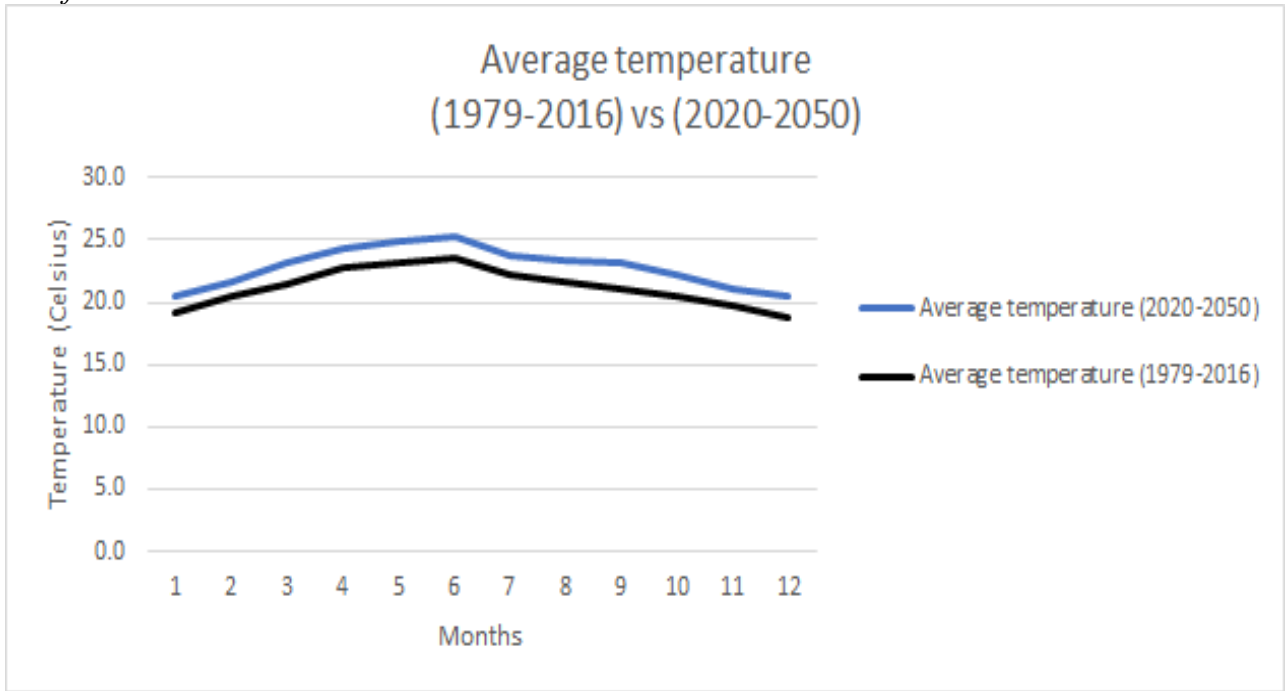

Figure 2: Differences in average temperature between the observed historical data and the future predicted temperature. Based on observed weather data and climate models.

Possible positive and negative changes in variability and intensity of the climate in the CRV make the predictions about future yield difficult. Mainly temperature will threaten food production in the CRV, Ethiopia, due to an increase in the average monthly temperature and the increase of extreme weather events. Therefore, the question arises if the current practices of farming will still be beneficial in the future and if adaptation strategies are necessary to ensure a safe food production. Information and data about current and other strategies are lacking. This report and the included results are conducted to enhance the availability of data.

\section{Research questions}

This case study deals with advising a smallholder farmer on how to implement agroforestry in his/her farm to sustainably increase productivity, while reducing the impact of agriculture on climate change, and increasing resilience of agricultural and food value chains. To investigate solutions on a farm-level also manure management, considering the interaction between the crop and the livestock, will be examined. The key pillars of 
climate smart agriculture, productivity, adaptation and mitigation, are of great importance in achieving the overall goal of this case study. Based on the challenges mentioned in the introduction we decided to research if agroforestry can be a potential management change for smallholder farmers in the CRV. Previous research has shown that agroforestry in Sub Saharan Africa can increase yields of different grain crops such as wheat, maize and sorghum(Birhane et al., 2018; Garrity et al., 2010; Glover et al., 2012; Kuyah et al., 2019; Sida, Baudron, Kim, et al., 2018). To research whether agroforestry is a suitable climate-smart option for farmers in the CRV this study proposes a main research question:

What is the effect of agroforestry as a CSA strategy option to improve food productivity in a mixed farming system at farm-level in CRV, Ethiopia?

To answer this main research question, the study posed several sub-questions:

1) What is the current situation in terms of food security and impacts on climate change?

2) What is the effect of climate change on maize yield in a business as usual scenario?

3) What is the simulated effect of agroforestry using the crop model WOFOST on maize yield?

4) What are the climate adaptation benefits when using agroforestry?

5) What are the climate mitigation benefits when using agroforestry?

6) How can we mitigate livestock impact on climate change?

\section{Methods}

To extrapolate current agricultural practices into the future WOFOST (The World Food Studies simulation model) was used to simulate the yield in under the effect of climate change. The input in WOFOST to simulate this was obtained from literature (Appendix A).

To mimic agroforestry in WOFOST several weather and soil parameters were changed based on literature research(Dilla et al., 2019; Sida, Baudron, Kim, et al., 2018; Yengwe et al., 2018). The first step was choosing a tree species where the potential benefits of agroforestry, such as adding nutrients to the soil and improve microclimatic conditions were maximised, while limiting competition for water, light and nutrients were minimised. Faidherbia albida is leguminous tree that is grown across Sub Saharan Africa, including Ethiopia, and is a suitable candidate for agroforestry for multiple reasons: it has a deep tap-root, making it drought resistant and reducing competition for water, it fixes nitrogen and therefore increases soil fertility and has it loses its leaves during the growing season ("reverse phenology") and therefore reducing light competition(Dilla et al., 2019; Garrity et al., 2010; Sida, Baudron, Kim, et al., 2018).

The parameters that were changed in WOFOST are listed in Table 1.

Table 1: Changed parameters used in the WOFOST model

\begin{tabular}{|l|l|l|l|}
\hline Parameter & Value & $\begin{array}{l}\text { Table 2: Changed parameters used in the WOFOST } \\
\text { model Directory }\end{array}$ & Source \\
\hline Temperature & $-4^{\circ} \mathrm{C}$ & Weatherdata (Rstudio) & Sida 2018a \\
\hline PAR & $-16 \%$ & Weatherdata (Rstudio) & Dilla 2019 \\
\hline Soil moisture & $+23 \%$ & EC2: SMFCF $=335$ & Dilla 2019 \\
\hline $\begin{array}{l}\text { Nitrogen } \\
\text { deposition }\end{array}$ & $60 \mathrm{~kg} / \mathrm{N} / \mathrm{ha}$ & WOFOST F30/30 & $\begin{array}{l}\text { Sida 2019; Yengwe } \\
2018\end{array}$ \\
\hline
\end{tabular}

A reduction of $4{ }^{\circ} \mathrm{C}$ was chosen based on the maximum reduction of $6{ }^{\circ} \mathrm{C}$. PAR: photosynthetically active radiation, $-16 \%$ was chosen average of the values of completely pruned trees $(-9 \%)$ and $50 \%$ pruned $(-23 \%)$. An increase of $60 \mathrm{~kg} / \mathrm{N} / \mathrm{ha}$ was chosen based on the rounded average of the values found in the literature.

To create the microclimate across the whole field it was proposed to plant 100 F.albida trees in a $10 \times 10 \mathrm{~m}$ grid where ploughing the field still practically feasible. As the trees become larger the number could be reduced to avoid competition for light(Garrity et al., 2010) .

\section{Results}

In this case study, different kinds of data have been generated for both the strategies and the historical results. In the next three subparagraphs, the results are showcased and explained.

\subsection{Historical situation}

The results of the historical yield are interesting to observe, since these can be compared with the future and with the adaptation strategy described in subsection 3.3. When observing figure 3, it can be noticed that it is difficult to determine the best sowing month. However, it does show the high variability in the past and large differences in yield. 


\section{Actual yield of sowing months \\ 1979-2015}

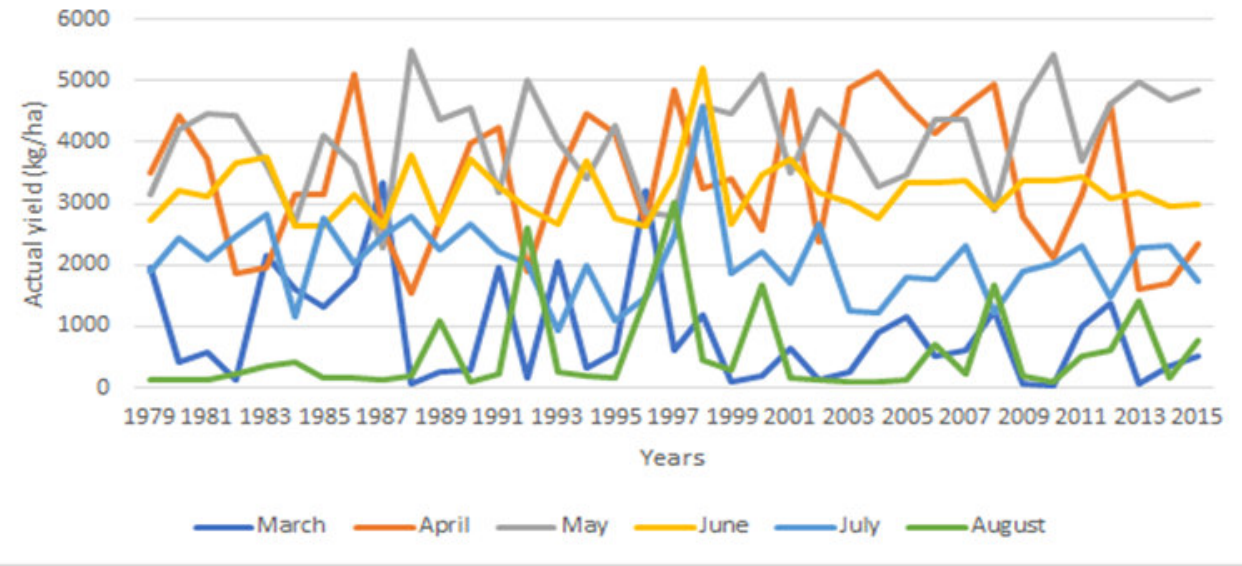

Figure 3: Potential yield from the past for different sowing months. WOFOST results based on historical weather data (1979-2015).

Figure 4 below, gives a better insight in the average and minimum yield per sowing month. It can be concluded that sowing in month May would have resulted in the best yield in both averages and minimum. Take in to account that minimum yield, as a very low yield in a particular year is not a feasible option for smallholder famers in Ethiopia. It is important to remember that these numbers are not the actual yield but potential yield when sowing has taken place in that month.

\section{Historical yield per sowing month}

\section{(1979-2015)}

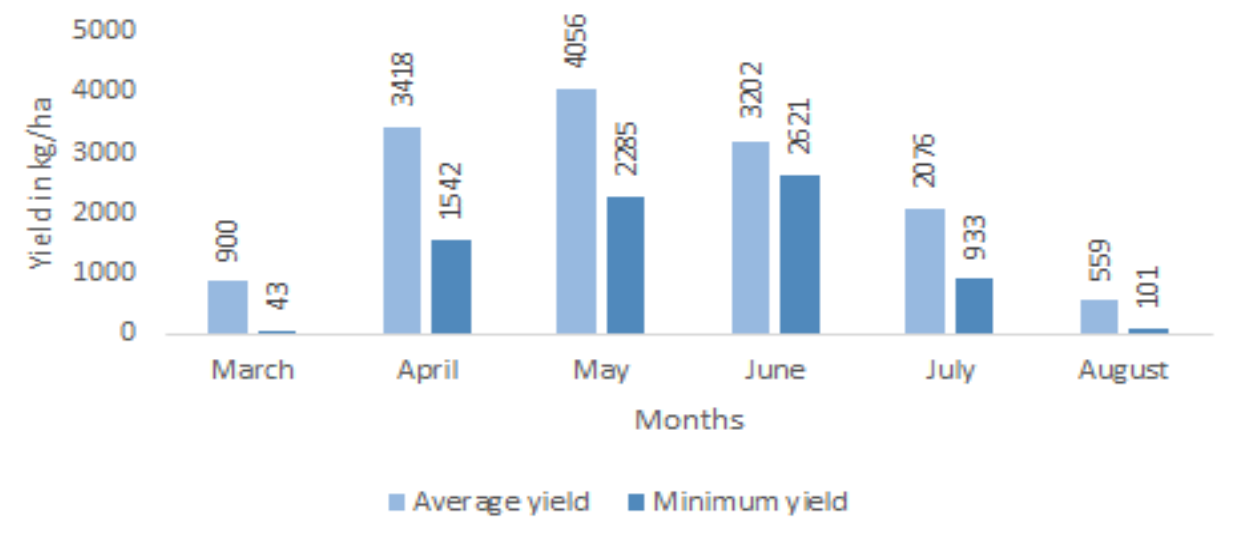

Figure 4: Average and minimum yields per month of the years 1979-2016 combined. WOFOST results based on observed weather data.

\subsection{Business as usual}

For the business as usual it is assumed that the strategies currently used by farmers remain the same in the future such as application of synthetic fertiliser and unavailability of irrigation systems. However, a few parameters will be changed due to climate change, such as amount of $\mathrm{CO}_{2}$ in the atmosphere. With the generated results it can be investigated if the sowing month can be postponed to a later moment in the year to increase the yield.

In figure 5, the average yield of the sowing months is shown per year. It can be concluded that the months July and June have the highest yield between the years 2020 and 2050. The standard deviation is acceptable, and the amount of yield remains stable for the next 30 years. However, figure 6 shows some interesting insight in the minimal yield and gives a better conclusion about which month is the best sowing month. 


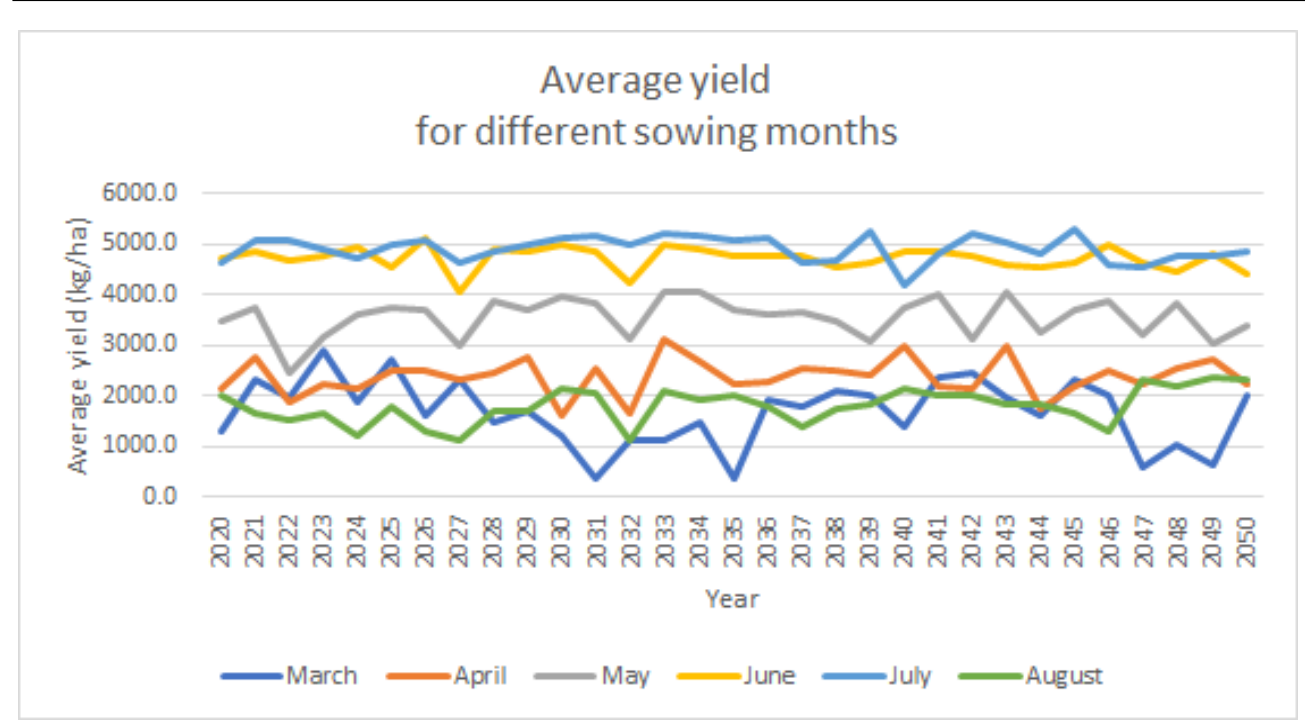

Figure 5: Potential yield for the future for different sowing months. WOFOST results based on projections from the climate models.

In figure 6 , the average yield and minimum yield are shown per sowing month as an average of the years 2020 to 2050. For example, sowing in March will result in an average yield of $\sim 1700 \mathrm{~kg} / \mathrm{ha}$ and a minimum yield of $\sim 100 \mathrm{~kg} / \mathrm{ha}$. The months July and June are, just like in figure 5, the best sowing months in terms of average yield. However, the minimum yield in July is much higher and thus guarantees a safer food productivity and reduces the risk for farmers. Therefore, it is highly recommended to change the sowing month from April, which is the main sowing month currently, to July.

Taking into consideration food security, one of the three pillars of Climate Smart Agriculture, the food demand for a farmer and its family should be self-sufficient. In Ethiopia a farm household consists of 3.8 adult equivalent, where 1 adult equivalent needs a minimum amount of $150 \mathrm{~kg} /$ year of cereal(Hengsdijk \& Verhagen, 2012). This means an average family needs around $600 \mathrm{~kg} / \mathrm{year}$ to sustain themselves in terms of food security. Going back to the graph, the minimum yield in June is barely enough to sustain a family in Ethiopia. This shows the importance of a safe and certain amount of minimal yield.

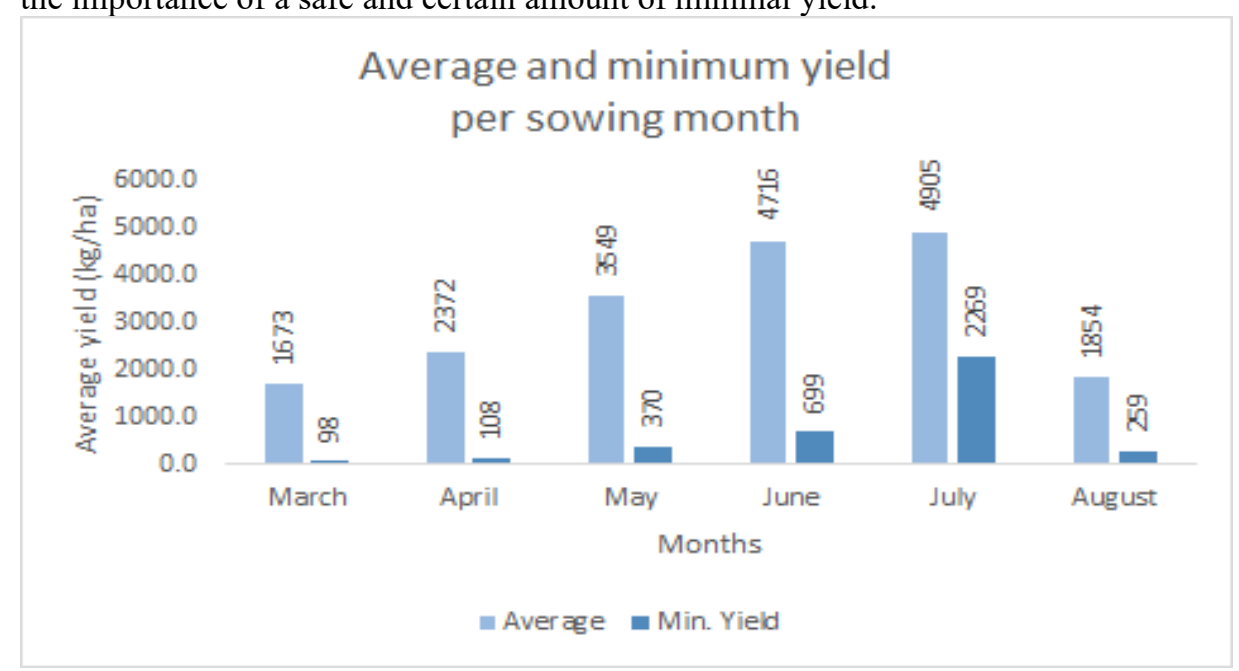

Figure 6: Average and minimum predicted yields per month of the years 2020-2050 combined. WOFOST results based on weather data from the climate models.

Looking back at the graphs of the historical yields, it can be concluded that yield will increase in the future. Also, the best sowing month is shifting from May to July.

\subsection{Agroforestry}

The results in the poster show a clear increase of maize yield compared to the business as usual scenario. These results are based on the integration of a change in manure management combined with agroforestry, where nitrogen is added to the soil through manure and agroforestry. We also ran WOFOST to model yield differences based just on agroforestry effects. These are shown in figure 7. 


\section{Ymax, Yavg and Ymin for different management options (July, 2020-2050)}

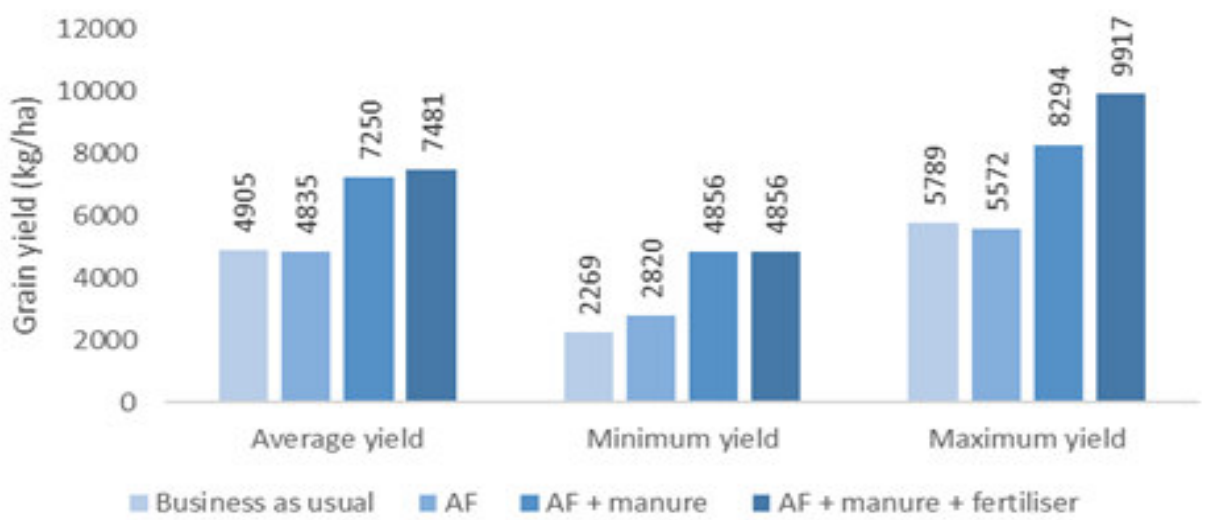

Figure 7: Compared results of Business as usual, Agroforestry, Agroforestry + manure, Agroforestry + manure + fertiliser. Future prediction for average, minimal and maximum yield.

\section{Mitigation}

When considering management options for smallholder farmers that benefit mitigation, it is important that these measures do not negatively influence food security and adaptation, as these are more important from the farmer's point of view. The role of agroforestry with F.albida in mitigation is twofold: carbon sequestration due to increased biomass and soil organic matter and reduced emissions that are associated with fertilizer use due to its ability to fix atmospheric nitrogen. To reduce emissions from livestock we suggest using an anaerobic digester, where the manure is digested and methane produced is tapped and used as a clean energy source to the households (Pathak, 2008). The manure can then be used to apply it on the fields and the methane can be used as fuel to replace the manure. We quantified emissions and uptake for different on-farm processes (table 2).

To quantify organic matter loss and uptake in the soil we used the excel file "Emissions_N2O_CH4", tab F_lu, F_mg, F_I. We assumed F_lu to be an average value of 0.79 between the "cultivated" value $(0.58)$ and the "perennial tree crop" value (1) to simulate intercropping maize with trees. See appendix B for the full calculations. We assume that $40 \%$ of the manure is left on the field and not collected.

Table 2: Emissions of on-farm processes for business as usual and Agroforestry + manure scenarios

\begin{tabular}{|l|l|l|}
\hline & Business as usual & Agroforestry + manure \\
\hline OM & 7,24 & $-1,33$ \\
\hline NO2 & & \\
\hline Fertiliser & 0,25 & 0 \\
\hline Manure app pasture & 0,81 & 0,81 \\
\hline Manure storage & 0 & 0 \\
\hline AF & 0 & 0,5 \\
\hline Burning manure & 0,24 & 0 \\
\hline Manure application & 0 & 1,21 \\
\hline CH4 & & \\
\hline Burning CH4 gas & 0 & 0 \\
\hline Burning manure & 0,87 & 0 \\
\hline Enteric fermentation & 3,47 & 3,47 \\
\hline Manure storage & 0 & 0 \\
\hline CO2 & & \\
\hline Avoided emissions synthetic fertiliser & 0 & $-0,13$ \\
\hline Total emissions & 12,89 & 4,53 \\
\hline Values are in tCoq/farm/year & \\
\hline
\end{tabular}

Values are in $\mathrm{tCO}_{2} \mathrm{eq} /$ farm/year.

The availability of manure as a fertiliser and the N-fixating capacity of the agroforestry practices results in an increase organic matter into the soil (biomass and manure) and will therefore enhance carbon sequestration. Another advantage of using manure and agroforestry is that both increase the $\mathrm{N}$ concentration in the soil. We examined whether it would be beneficial for the yield to further increase the $\mathrm{N}$ content by adding synthetic fertiliser to the soil. The $\mathrm{N}$ input into the soil for each of these strategies is shown in table 3 . By examining the 
amount of yield per $\mathrm{N}$ application it can be concluded that it is not beneficial to use synthetic fertiliser because manure and agroforestry already enhanced the $\mathrm{N}$ content of the soil sufficiently (table 4).

Table 3: N-management strategies

\begin{tabular}{|l|l|l|l|}
\hline N-management strategy & $\begin{array}{l}\text { Total } \\
\text { N application (kg N/ha) }\end{array}$ & Application 1 (kg N/ha) & Application 2 (kg N/ha) \\
\hline Synthetic fertiliser (SF) & 60 & 40 & 20 \\
\hline Agroforestry (AF) & 60 & 30 & 30 \\
\hline Manure (M) & 66 & 66 & 0 \\
\hline SF + AF + M & 186 & 136 & 50 \\
\hline AF + M & 126 & 96 & 30 \\
\hline
\end{tabular}

Table 4: Amount of yield per $\mathrm{N}$ application

\begin{tabular}{|l|l|l|l|l|l|}
\hline Management & N applied $(\mathrm{kg})$ & Y avg $(\mathrm{kg})$ & $\mathrm{Y}$ avg/N & Y max $(\mathrm{kg})$ & $\mathrm{Y} \max / \mathrm{N}$ \\
\hline $\mathrm{F}+\mathrm{AF}+\mathrm{M}$ & 186 & 7481 & 40,22043 & 9917 & 53,3172 \\
\hline $\mathrm{AF}+\mathrm{M}$ & 126 & 7250 & 57,53968 & 8294 & 65,8254 \\
\hline
\end{tabular}

The nitrogen fixed by F.albida can be seen as permanent avoided emissions from fertilizer manufacturing (Haskett et al. 2019). We assume the average nitrogen deposition by F.albida in Ethiopia to be $60 \mathrm{~kg} / \mathrm{N} / \mathrm{ha}$ (Sida et al., 2019; Yengwe et al., 2018). With that amount of nitrogen, the avoided emissions from fertilizer manufacturing and transport will then be $0.132 \mathrm{tCO}_{2} \mathrm{eq} / \mathrm{ha} /$ year . See (Haskett et al., 2019)for the formulas used. Based on these measures we can reduce total emissions by $8,36 \mathrm{tCO}_{2} \mathrm{eq} /$ year.

\section{Adaptation}

Heat stress is an important limiting factor for maize yields in Africa, with yields decreasing by $1 \%$ for each day above $30^{\circ} \mathrm{C}$ under optimal rainfed conditions and $1,7{ }^{\circ} \mathrm{C}$ under drought conditions (Lobell et al. 2010). With current climate predictions of increasing temperatures these conditions will be more common in the future. Adaptive strategies that alleviates heat stress will therefore be important for management considerations for smallholder farmers in Sub Saharan Africa. Agroforestry to change the microclimate is a potential option for adaptation. In an experiment done in the Central Rift Valley in Ethiopia, incorporating $F$. albida trees has been shown to reduce the maximum daytime temperature by $6{ }^{\circ} \mathrm{C}$ under the canopy and reducing heat stress and water use efficiency of the wheat crop(Sida, Baudron, Kim, et al., 2018)

Soil erosion by water and wind is another important problem in the Central Rift Valley, which is exacerbated by deforestation for crop cultivation(Meshesha et al., 2012). With increasing rainfall intensity predicted by climate change as shown in the modelled results soil erosion will likely increase. Agroforestry has been shown to reduce soil erosion by increasing soil structure and water infiltration and reducing runoff, which increase the water availability for the crop (Kuyah et al. 2019).

Nutrient availability is another major factor causing yield gaps for smallholder farmers in Sub Saharan Africa, as inputs are generally too low to sustain good yields. Beside the low inputs, many soils are unresponsive to fertilizer application due to low organic matter content and biological activity(Sida et al., 2019). To overcome this nutrient deficit, legumes are often used to improve soil fertility due to their ability to fix atmospheric nitrogen. Nitrogen deposition by F.albida is reported to be $34-83 \mathrm{~kg} / \mathrm{N} / \mathrm{ha}$ with higher values for older trees (Yengwe et al., 2018), while another study reported a deposition of $64 \mathrm{~kg} / \mathrm{N} / \mathrm{ha}$ (Sida et al., 2019). These values are similar to average mineral fertiliser input of $65 \mathrm{~kg} / \mathrm{N} / \mathrm{ha}$ by farmers in the Central Rift Valley (Silva et al. 2019). Because the manure can be used as input in the field an extra $65 \mathrm{~kg} / \mathrm{N} / \mathrm{ha}$ can be added, effectively able to replace synthetic fertiliser and therefore reduce costs for the farmer.

Other benefits making farmers more resilient to climate change when incorporating agroforestry include an increase in biodiversity (Garrity et al. 2010), diversification of resources such as firewood and building material(Bekele, 2018; Dilla et al., 2019; Garrity et al., 2010), honey production (Bekele, 2018) and income diversification(Birhane et al., 2019).

\section{Discussion and conclusion}

The study revealed that the combined effects of agroforestry and enhanced manure management is a strategy that is climate smart according to the three CSA pillars. The study show that farmers can increase their production without relying on synthetic fertilisers, which makes them less vulnerable to fluctuating prices while maintaining a stable yield.

However, agroforestry is not always beneficial to crop yields, as competition for light, water and nutrients can occur and yields of cereal crops are not always positively affected by incorporation of trees(Nyaga et al., 2019; Sida, Baudron, Hadgu, et al., 2018).Reducing competition, while maintaining the positive effects associated with agroforestry, is therefore very important. Tree management is a crucial factor that will determine 
success. In a study done in the CRV of Ethiopia it was shown that pruning increased maize yields compared to unpruned trees by reducing competition for light(Dilla et al., 2019).

Agroforestry can be used to mitigate climate change, but the extent of that is unclear and the values reported in literature are variable and often based on (sometimes erroneous) assumption (Nair \& Nair, 2014).

When trying to improve food security for smallholder farmers it is not enough to just look at yield. Income is another important indicator which will be influenced when changing farming practices. Tree products such as firewood, building material and fodder can be used on-farm, but can also be sold to increase farm income. Acacia polycantha, another leguminous tree species, contributed up to $13,7 \%$ of the total household income of farmers in Tigray, northern Ethiopia(Birhane et al., 2019) .

Models like WOFOST are very useful tools to assess yield gaps due to climate change and potential management options such as changing the planting date, fertiliser application etc. However, using the model to mimic agroforestry is based on several assumptions and not all variables that are associated with agroforestry (water infiltration, SOM) can be incorporated in the model. Another limitation of WOFOST is that it only considers the potential and attainable yield and not yield decreasing factors such as pests and diseases. However, these can be very important in terms of yield reductions, which can potentially be alleviated by agroforestry. An experiment done in the Tigray region of Ethiopia reported a decrease of striga infestation on sorghum. Striga (Striga hermonthica) is a hemi-parasitic weed of maize and sorghum, significantly reducing yields (Birhane et al., 2018). In other words, when considering agroforestry, it is important to consider all aspects associated with its incorporation.

While the results of this study show a very positive effect of agroforestry in combination with enhanced manure management, it is important to take the practical limitations into account. To implement these measurements the farmer would have to invest in tree seedlings and the anaerobic digester, and this might not be possible all at once even when considering the reduced cost of not having to buy fertiliser. Another limitation is that these measures might increase labour demand. We did not quantify these limitations, but they will be when considering implementing them.

All things considered, this study recommend using agroforestry with enhanced manure management as a climate smart strategy that will improve all CSA pillars. The multiple benefits associated with agroforestry, when managed well, are a viable option for smallholder farmers of the Central Rift Valley of Ethiopia.

\section{References}

Adger, W. N., Arnell, N. W., \& Tompkins, E. L. (2005). Successful adaptation to climate change across scales. Global Environmental Change 15: 77-86. Global Environmental Change. https://doi.org/DOI 10.1016/j.gloenvcha.2004.12.005

Bekele, S. E. (2018). Parkland Agroforestry of Ethiopia; Key to Production, Productivity, Biodiversity Conservation and Climate Change Mitigation: A Review. Open Journal of Forestry, 08(04), $472-488$. https://doi.org/10.4236/ojf.2018.84030

Birhane, E., Gebremeskel, K., Taddesse, T., Hailemariam, M., Hadgu, K. M., Norgrove, L., \& Negussie, A. (2018). Integrating Faidherbia albida trees into a sorghum field reduces striga infestation and improves mycorrhiza spore density and colonization. Agroforestry Systems, 92(3), $643-653$. https://doi.org/10.1007/s10457-016-0027-8

Birhane, E., Teklay, R., Gebrehiwet, K., Solomon, N., \& Tadesse, T. (2019). Maintaining Acacia polyacantha trees in farmlands enhances soil fertility and income of farmers in North Western Tigray, Northern Ethiopia. Agroforestry Systems, 93(6), 2135-2149. https://doi.org/10.1007/s10457-018-0328-1

Dilla, A. M., Smethurst, P. J., Barry, K., Parsons, D., \& Denboba, M. A. (2019). Tree pruning, zone and fertiliser interactions determine maize productivity in the Faidherbia albida (Delile) A. Chev parkland agroforestry system of Ethiopia. Agroforestry Systems, 93(5), 1897-1907. https://doi.org/10.1007/s10457-018-0304-9

Garrity, D. P., Akinnifesi, F. K., Ajayi, O. C., Weldesemayat, S. G., Mowo, J. G., Kalinganire, A., Larwanou, M., \& Bayala, J. (2010). Evergreen Agriculture: A robust approach to sustainable food security in Africa. Food Security, 2(3), 197-214. https://doi.org/10.1007/s12571-010-0070-7

Glover, J., Reganold, J., \& Cox, C. (2012). Plant perennials to save Africa's soils. Nature, 489, 359-361.

Haskett, J. D., Simane, B., \& Smith, C. (2019). Energy and Climate Change Mitigation Benefits of Faidherbia albida Agroforestry in Ethiopia. Frontiers in Environmental Science, 7(November), 1-15. https://doi.org/10.3389/fenvs.2019.00146

Hengsdijk, H., \& Verhagen, A. (2012). A bio-economic farm household model to assess cropping systems in the Rift valley of Ethiopia : towards climate smart agriculture: do food security and mitigration goals match? http://www.narcis.nl/publication/RecordID/oai:library.wur.nl:wurpubs\%2F423014

Kuyah, S., Whitney, C. W., Jonsson, M., Sileshi, G. W., Öborn, I., Muthuri, C. W., \& Luedeling, E. (2019). Agroforestry delivers a win-win solution for ecosystem services in sub-Saharan Africa. A meta-analysis. Agronomy for Sustainable Development, 39(5). https://doi.org/10.1007/s13593-019-0589-8 
Lobell, D. B., Bänziger, M., Magorokosho, C., \& Vivek, B. (2011). Nonlinear heat effects on African maize as evidenced by historical yield trials. Nature Climate Change, 1(1), 42-45. https://doi.org/10.1038/nclimate1043

Lobell, D. B., \& Field, C. B. (2007). Global scale climate-crop yield relationships and the impacts of recent warming. Environmental Research Letters. https://doi.org/10.1088/1748-9326/2/1/014002

Meehl, G. A., Stocker, T. F., Collins, W. D., Friedlingstein, P., Gaye, A. T., Gregory, J. M., Kitoh, A., Knutti, R., Murphy, J. M., Noda, A., Raper, S. C. B., Watterson, I. G., Weaver, A. J., \& Zhao, Z.-C. (2007). Global Climate Projections. In Climate Change 2007: The Physical Science Basis. Contribution of Working Group I to the Fourth Assessment Report of the Intergovernmental Panel on Climate Change.

Meshesha, D. T., Tsunekawa, A., Tsubo, M., \& Haregeweyn, N. (2012). Dynamics and hotspots of soil erosion and management scenarios of the Central Rift Valley of Ethiopia. International Journal of Sediment Research, 27(1), 84-99. https://doi.org/10.1016/S1001-6279(12)60018-3

Nair, P. R., \& Nair, V. D. (2014). Solid-fluid-gas: The state of knowledge on carbon-sequestration potential of agroforestry systems in africa. Current Opinion in Environmental Sustainability, 6(1), $22-27$. https://doi.org/10.1016/j.cosust.2013.07.014

Nyaga, J., Muthuri, C. W., Barrios, E., Öborn, I., \& Sinclair, F. L. (2019). Enhancing maize productivity in agroforestry systems through managing competition: lessons from smallholders' farms, Rift valley, Kenya. Agroforestry Systems, 93(2), 715-730. https://doi.org/10.1007/s10457-017-0169-3

Sida, T. S., Baudron, F., Hadgu, K., Derero, A., \& Giller, K. E. (2018). Crop vs. tree: Can agronomic management reduce trade-offs in tree-crop interactions? Agriculture, Ecosystems and Environment, 260(April), 36-46. https://doi.org/10.1016/j.agee.2018.03.011

Sida, T. S., Baudron, F., Kim, H., \& Giller, K. E. (2018). Climate-smart agroforestry: Faidherbia albida trees buffer wheat against climatic extremes in the Central Rift Valley of Ethiopia. Agricultural and Forest Meteorology, 248(March 2017), 339-347. https://doi.org/10.1016/j.agrformet.2017.10.013

Sida, T. S., Baudron, F., Ndoli, A., Tirfessa, D., \& Giller, K. E. (2019). Should fertilizer recommendations be adapted to parkland agroforestry systems? Case studies from Ethiopia and Rwanda. Plant and Soil. https://doi.org/10.1007/s11104-019-04271-y

Silva, J. V., Baudron, F., Reidsma, P., \& Giller, K. E. (2019). Is labour a major determinant of yield gaps in subSaharan Africa? A study of cereal-based production systems in Southern Ethiopia. Agricultural Systems, 174(April), 39-51. https://doi.org/10.1016/j.agsy.2019.04.009

T., W., \& J., V. B. (2013). Climate change impacts on global food security. Science.

van de Steeg, J., Herrero, M., Kinyangi, J., Thornton, P., Rao, K., Stern, R., \& Cooper, P. (2009). The influence of climate variability and climate change on the agricultural sector in East and Central Africa-Sensitizing the ASARECA strategic plan to climate change. Research report 22. In ILRI (International Livestock Research Institute), Nairobi, Kenya, ICRISAT (International Crop Research Institute for the Semi-Arid Tropics), Nairobi, Kenya, and ASARECA (Association for Strengthening Agricultural Research in Eastern and Central Africa),.

Yengwe, J., Amalia, O., Lungu, O. I., \& De Neve, S. (2018). Quantifying nutrient deposition and yield levels of maize (Zea mays) under Faidherbia albida agroforestry system in Zambia. European Journal of Agronomy, 99(April 2017), 148-155. https://doi.org/10.1016/j.eja.2018.07.004 


\section{Appendix A: Input data WOFOST model}

The food productivity is often determined by the amount of yield generated from the farmer(s). In this case study the yield is calculated by the model WOFOST (World Food Studies). In order to run the model, a few parameters should be determined. In the table below, the parameters necessary and the values used for this case study are described. Some of the parameters were given from the assignment description while others were determined based on literature or assumptions necessary to calculate a yield.

\begin{tabular}{|c|c|c|}
\hline Parameter & Value & Reference \\
\hline Crop_name & mag201.cab & WOFOST files provided from assignment \\
\hline Soil_name & E2.NEW & WOFOST files provided from assignment. \\
\hline Site_name & Ethiopia.site & WOFOST files provided from assignment. \\
\hline Years & $2020-2050$ & Range of this case study. \\
\hline $\mathrm{CO2}$ & $480 \mathrm{ppm}$ & $\begin{array}{l}\text { Average of } \mathrm{CO} 2 \mathrm{ppm} \text { between } 2020 \text { and } 2050 \text { for RCP } \\
8.5 \text {. }\end{array}$ \\
\hline TSUM1 & 1000 & Based on input Iwan Supit. \\
\hline TSUM2 & 1200 & Based on input Iwan Supit. \\
\hline Sowing date & $\begin{array}{l}\text { 15th of March, April, May, } \\
\text { June, July, August. }\end{array}$ & $\begin{array}{l}\text { Range of sowing dates for this case studies to compare the } \\
\text { different yields per month. }\end{array}$ \\
\hline end_type & maturity & $\begin{array}{l}\text { Assumption made in this case study. Yield is calculated } \\
\text { based on the end date of maturity. }\end{array}$ \\
\hline harvest & - & $\begin{array}{l}\text { Harvest date has to be determined but is not used by } \\
\text { WOFOST if maturity is used. }\end{array}$ \\
\hline F1 & $40 \mathrm{~kg}$ & Based on literature that farmers have $60 \mathrm{~kg} / \mathrm{ha}$ of manure. \\
\hline F2 & $20 \mathrm{~kg}$ & $\begin{array}{l}\text { Assumption that crops need more nitrogen in the } \\
\text { development stage (F1) than in the flowering stage (F2). }\end{array}$ \\
\hline D1 & $\begin{array}{l}\text { 5th of April, May, June, July, } \\
\text { August, September }\end{array}$ & Optimum is 3 weeks after sowing. \\
\hline D2 & $\begin{array}{l}\text { 5th of May, June, July, } \\
\text { August, September, October }\end{array}$ & Optimum of D1 + 1 month. \\
\hline $\begin{array}{l}\text { I1/I2 } \\
\text { DI1/DI2 }\end{array}$ & - & $\begin{array}{l}\text { No irrigation is used since we assume that the farmer is } \\
\text { depending on rainfed agriculture. }\end{array}$ \\
\hline Country & Ethiopia & Country code used by WOFOST. \\
\hline Code & ET & Abbreviation used by WOFOST. \\
\hline Models & $\begin{array}{l}\text { gfdl-esm2m, hadgem2-es, } \\
\text { ipsl-cm5a-lr, miroc-esm- } \\
\text { chem, noresm1-m }\end{array}$ & Models present in the assignments of WOFOST. \\
\hline
\end{tabular}




\section{Appendix B: Summary calculations emissions farm level}

Calculations Table 1

It was assumed that the soil type to be HAC dryland (value 44).

F lu: 0.58 , F mg: 1, F I: 0.95.

\begin{tabular}{|l|l|}
\hline \multicolumn{2}{|c|}{ Business as usual } \\
\hline Start $\mathrm{SOC}(0-\mathrm{T})$ & $44 \mathrm{tC} / \mathrm{ha}$ \\
\hline End SOC$(0-\mathrm{T})$ & $24,24 \mathrm{tC} / \mathrm{ha}$ \\
\hline Change in $\mathrm{C}$ stock per year & $-0,99 \mathrm{tC} / \mathrm{ha} / \mathrm{yr}$ \\
\hline $\mathrm{CO} 2$ emissions/ha/yr & $3,62 \mathrm{tCO} 2 / \mathrm{ha} / \mathrm{yr}$ \\
\hline $\mathrm{CO} 2$ emissions/farm/yr & $\mathbf{7 , 2 4} \mathrm{tCO} / \mathbf{f a r m} / \mathbf{y r}$ \\
\hline
\end{tabular}

F_lu: 0.79, F_mg: 1, F_I: 1.37 .

\begin{tabular}{|c|c|}
\hline \multicolumn{2}{|c|}{ Manure + agroforestry } \\
\hline Start SOC $(0-T)$ & $44 \mathrm{tC} / \mathrm{ha}$ \\
\hline End $\operatorname{SOC}(0-\mathrm{T})$ & $47,62 \mathrm{tC} / \mathrm{ha}$ \\
\hline Change in $\mathrm{C}$ stock per year & $0,18 \mathrm{tC} / \mathrm{ha} / \mathrm{yr}$ \\
\hline $\mathrm{CO} 2$ emissions/ha/yr & $-0,66$ tCO2/ha/yr \\
\hline $\mathrm{CO} 2$ emissions/farm/yr & $-1,33 \mathrm{tCO2} / \mathrm{farm} / \mathrm{yr}$ \\
\hline
\end{tabular}

Amount of manure excreted per year: 240 (weight animal) * 4 animals * 0,055 (factor manure produced/day) * $365=19272 \mathrm{~kg}$ manure $/ \mathrm{yr}$

$60 \%$ burned or applied to crops: $0,6 * 19272=11563 \mathrm{~kg}$

\section{N2O emissions:}

Synthetic fertiliser: $60 \mathrm{~kg} / \mathrm{ha} * 0.005 * 2 \mathrm{ha} *(44 / 28) * 265=0,25 \mathrm{tCO} 2 \mathrm{eq}$

Amount of nitrogen from manure (tab N2O): $240 \mathrm{~kg} * 0,63 * 365 * 60 \%=130 \mathrm{~kg} / \mathrm{N} / \mathrm{yr}$.

Manure left on pasture: $((88 \mathrm{~kg} / \mathrm{N} / \mathrm{yr} * 0,02)+(88 * 0,02 * 0,02)) *(44 / 28) * 265=0,81 \mathrm{tCO} 2 \mathrm{eq}$

AF: $60 \mathrm{~kg} / \mathrm{ha} * 0.01 * 2 \mathrm{ha} *(44 / 28) * 265=0,5 \mathrm{tCO} 2 \mathrm{eq}$

Manure burning: $130 \mathrm{~kg} / \mathrm{N} * 0,007$ conversion factor (Oenema et al. 2005) $* 265=0,24 \mathrm{tCO} 2 \mathrm{eq}$

Manure application crops: $((132 \mathrm{~kg} / \mathrm{N} / \mathrm{yr} * 0,02)+(132 * 0,02 * 0,02)) *(44 / 28) * 265=1,21 \mathrm{tCO} 2 \mathrm{eq}$

CH4 emissions:

Burning manure: $11563 \mathrm{~kg}$ manure $* 0,0027$ emission factor (Oshita 2012) $* 28=0,875 \mathrm{tCO} 2 \mathrm{eq}$

Enteric fermentation: $4 * 31(\mathrm{~kg} / \mathrm{CH} 4 /$ head/year $) * 28=3,47 \mathrm{tCO} 2 \mathrm{eq}$ 